\title{
Concrete Cleałning, Inc. Centrifugal Shot Blaster: Baseline Report
}

\section{Topical Report July 31, 1997}

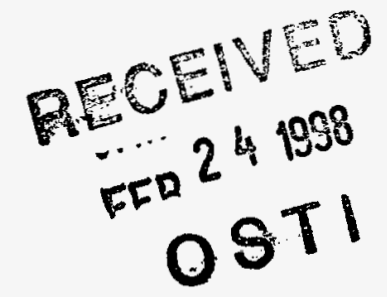

Work Performed Under Contract No.: DE-FC21-95MC32260

For

U.S. Department of Energy

Office of Environmental Management

Office of Technology Development

1000 Independence Avenue

Washington, DC 20585
U.S. Department of Energy

Office of Fossil Energy

Federal Energy Technology Center

Morgantown Site

P.O. Box 880

Morgantown, West Virginia 26507-0880

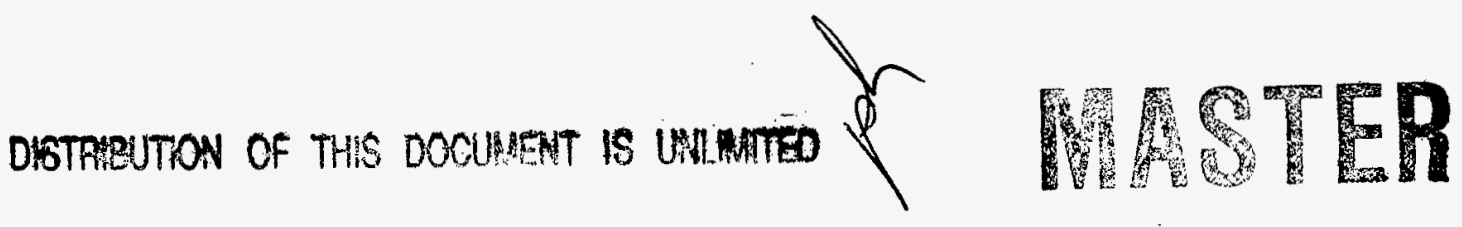

By

DTIC QUALTI IREDETTED 5

Operating Engineers National Hazmat Program

250 Airport Circle

Beaver, West Virginia 25813 


\section{Disclaimer}

This report was prepared as an account of work sponsored by an agency of the United States Government. Neither the United States Government nor any agency thereof, nor any of their employees, makes any warranty, express or implied, or assumes any legal liability or responsibility for the accuracy, completeness, or usefulness of any information, apparatus, product, or process disclosed, or represents that its use would not infringe privately owned rights. Reference herein to any specific commercial product, process, or service by trade name, trademark, manufacturer, or otherwise does not necessarily constitute or imply its endorsement, recommendation, or favoring by the United States Government or any agency thereof. The views and opinions of authors expressed herein do not necessarily state or reflect those of the United States Government or any agency thereof. 


\section{CONCRETE CLEANING, INC. CENTRIFUGAL SHOT BLAST}

\section{TABLE OF CONTENTS}

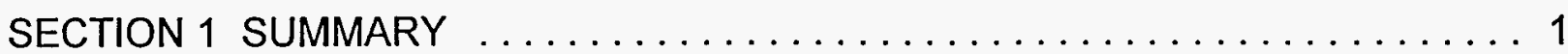

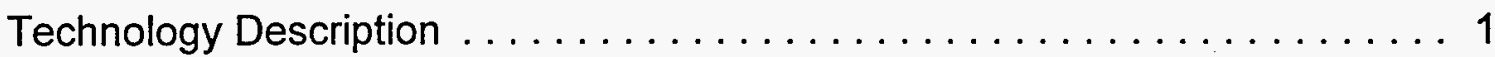

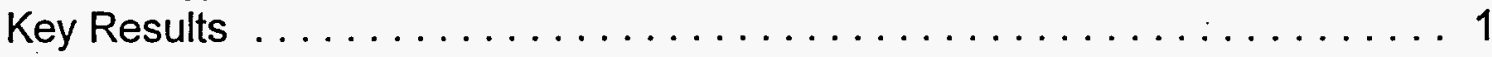

SECTION 2 -TECHNOLOGY DESCRIPTION $\ldots \ldots \ldots \ldots \ldots \ldots \ldots \ldots \ldots \ldots$

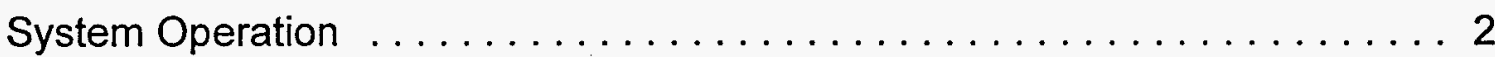

SECTION 3 - HEALTH AND SAFETY EVALUATION $\ldots \ldots \ldots \ldots \ldots \ldots \ldots \ldots 2$

General Health and Safety Concerns $\ldots \ldots \ldots \ldots \ldots \ldots \ldots \ldots \ldots \ldots \ldots \ldots \ldots$

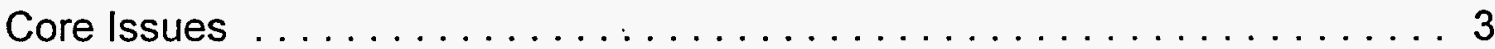

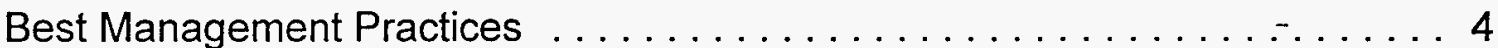

Industrial Hygiene Monitoring $\ldots \ldots \ldots \ldots \ldots \ldots \ldots \ldots \ldots \ldots \ldots$

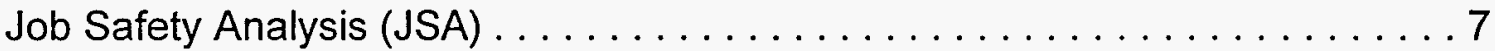

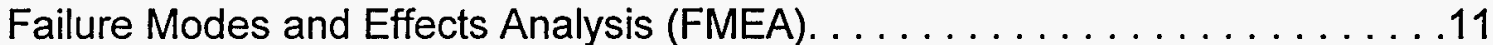

Technology Safety Data Sheet (TSDS) . . . . . . . . . . . . . . 12

Human Factors Interface . . . . . . . . . . . . . . . . . . 18

Emergency Response/Preparedness $\ldots \ldots \ldots \ldots \ldots \ldots \ldots \ldots \ldots$

SECTION 4 - TECHNOLOGY APPLICABILITY ................. 19

SECTION 5 - REGULATORYIPOLICY ISSUES . . . . . . . . . . . . . . . . 19

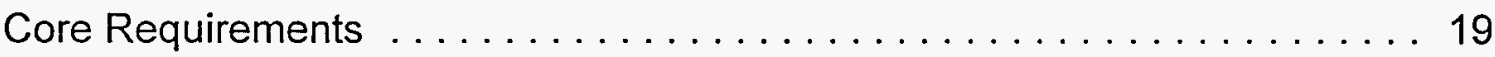

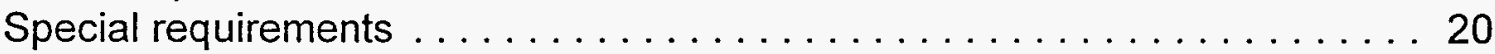

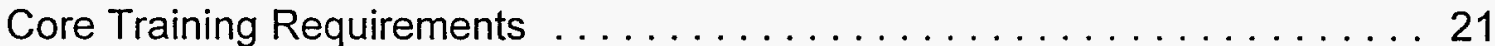

Technology-specific Training . . . . . . . . . . . . . . . . . . 21

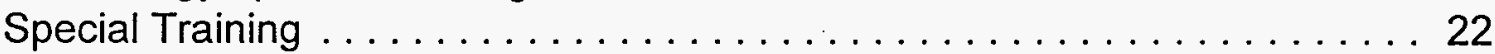

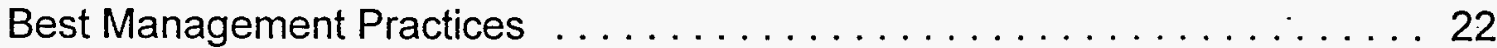

SECTION 6 - OPERATIONAL CONSIDERATIONS AND

RECOMMENDATIONS ........................ 22

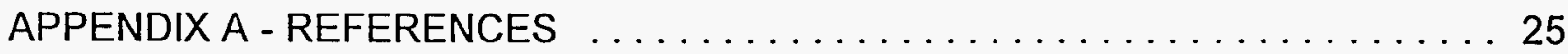

APPENDIX B - INDUSTRIAL HYGIENE DATA . . . . . . . . . . . . . 26 


\section{Concrete Cleaning, Inc. Centrifugal Shot Blaster \\ Human Factors Evaluation}

\section{SECTION 1 - SUMMARY}

\section{TECHNOLOGY DESCRIPTION}

The centrifugal shot blaster technology was tested and is being evaluated at Florida International University (FIU) as a baseline technology. In conjunction with FIU's evaluation of efficiency and cost, this report covers the evaluation conducted for safety and health issues. It is a commercially available technology and has been used for various projects at locations throughout the country.

The centrifugal shot blaster is an electronically operated shot blast machine that has been modified to remove layers of concrete to varying depths. A hardened steel shot propelled at a high rate of speed abrades the surface of the concrete. The depth of material removed is determined by the rate of speed the machine is traveling and the volume of shot being fired into the blast chamber. The steel shot is recycled and used over until it is pulverized into dust, which ends up in the waste container with the concrete being removed. Debris is continually vacuumed by a large dust collection system attached to the shot blaster.

\section{KEY RESULTS}

The safety and health evaluation during the testing demonstration focused on two main areas of exposure: dust and noise. The dust exposure was minimal, but noise exposure was potentially significant. Further testing for each of these exposures is recommended because the outdoor environment where the testing demonstration took place may cause the results to be inapplicable to enclosed operating environments, where it is feasible that the dust and noise levels will be higher. Other safety and health issues found were ergonomics, heat stress, tripping hazards, electrical hazards, and lockout/tagout. 


\section{SECTION 2 \\ TECHNOLOGY DESCRIPTION}

\section{SYSTEM OPERATION}

The centrifugal shot blaster technology was tested and is being evaluated at Florida

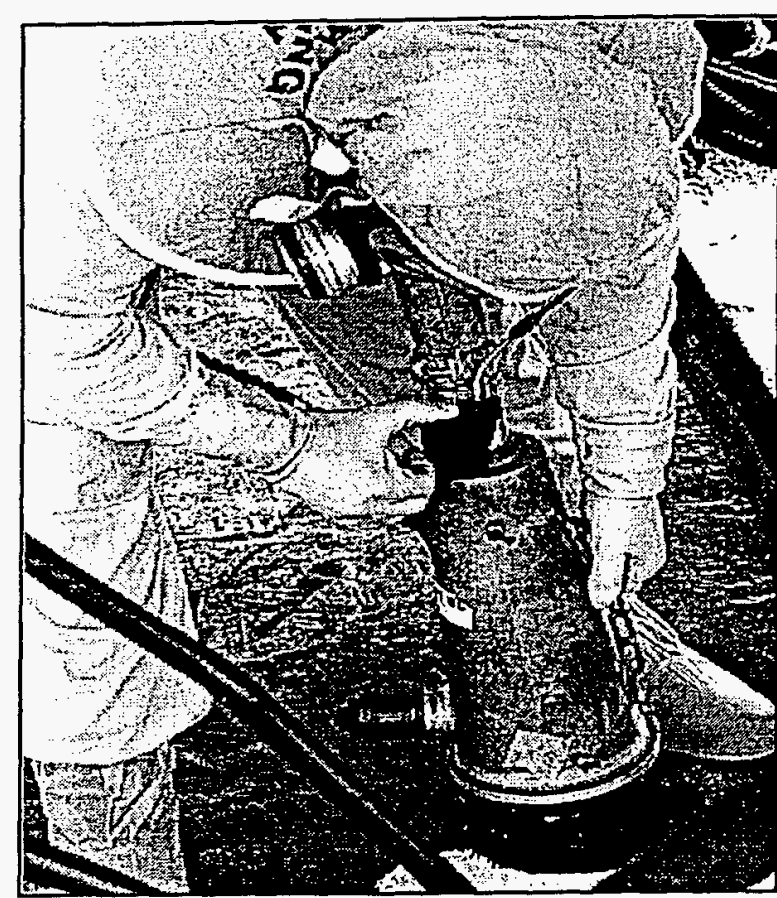

Figure 1- Manual operation of shotblast head. International University (FIU) as a baseline technology. In conjunction with FIU's evaluation of efficiency and cost, this report covers the evaluation conducted for safety and health issues. It is a commercially available technology and has been used for various projects at locations throughout the country.

The centrifugal shot blaster is an electronically operated shot blast machine that has been modified to remove layers of concrete to varying depths. A hardened steel shot propelled at a high rate of speed abrades the surface of the concrete. The depth of material removed is determined by the rate of speed the machine is traveling and the volume of shot being fired into the blast chamber. The steel shot is recycled and used over until it is pulverized into dust, which ends up in the waste container with the concrete being removed. Debris is continually vacuumed by a large dust collection system attached to the shot blaster. The vacuum system utilizes high efficiency particulate (HEPA) filters.

\section{SECTION 3}

\section{HEALTH AND SAFETY EVALUATION}

\section{GENERAL SAFETY AND HEALTH CONCERNS}

Personnel where the centrifugal shot blaster technology is being used need to be concerned with safety and health issues. Issues that personnel need to be cognizant of may be divided into two categories. Core issues are those that are based on current safety and health regulatory requirements. Best management practices are related to issues that are not based on current safety and health regulations but are key elements in preventing worker injury and illness on the job. 
Safety and health issues of concern with the centrifugal shot blaster technology included:

\section{Core Issues:}

- Tripping hazards - the electric cords needed to operate the equipment are tripping hazards. Therefore, the need for stringent housekeeping must be evaluated.

- Pinch points - the potential exists for the operator to have his/her fingers/hand crushed if during operation the hand is placed in the area of the shot head or near any moving parts of the equipment. Blasting mode should never be activated while maintenance is being conducted on the head. This will be consiciered under a lockout/tagout program.

- Electrical hazards - the generator and electric cords necessary to operate the equipment can present electrical hazards, therefore, the need for ground fault circuit interrupters, grounding, and strain relief must be evaluated.

Lockout/Tagout - the user of the technology will need to develop a lockout/tagout program to assure there is not an accidental release of energy during maintenance/repair activities.

Noise - the user was subjected to a potentially significant amount of noise while operating the centrifugal shot blast.

Dust - the equipment did not generate visible dust during operation, but larger debris and shot were left on the surface being blasted. The amount of dust generated in the breathing zone of the operator may change based on the environment in which the concrete decontamination is taking place; therefore, the user of the technology will need to develop a sampling plan based on the individual site needs. It should also be noted that there was potential for contamination by dust when emptying the collection pan.

A large amount of shot was left on the surface during blasting operations. This has the potential to become an airborne hazard, especially after the shot is pulverized to a dust. Additionally, the

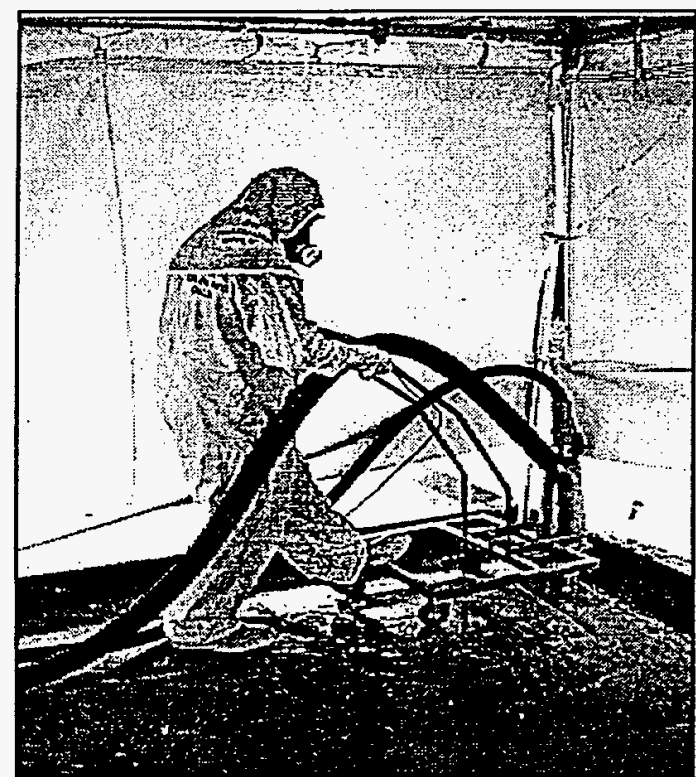

Figure 2 - Shotblast head attached to cart. 
shot left on the surface caused the surface to become very slippery.

\section{Best Management Practices:}

- Heat stress - the operator was subjected to an increase in heat stress due to the need to utilize Anti-C PPE. The user will need to develop a heat stress program for the environment in which the technology is being used, taking into consideration any PPE that may need to be utilized.

- Ergonomics - the user was subjected to some ergonomic stressors that need to be taken into consideration, such as, stooping, bending, twisting, kneeling, and lifting. Of particular concern is the need to manually shovel the dust and debris from the dust pan. This adds an ergonomic stressor to the back, and causes an increase in exposure to the contaminant.

- Struck by hazards - there is potential for ancillary personnel in the area to be struck by or pinned by the operating shot blaster. The operator cannot see directly in front of the machine during operation. Additionally, the equipment was able to continue running even when the operator stepped away from it. This could lead to serious injury to the operator or other personnel in the area. The equipment needs to be fitted with a "dead man switch" in order to keep this from happening.

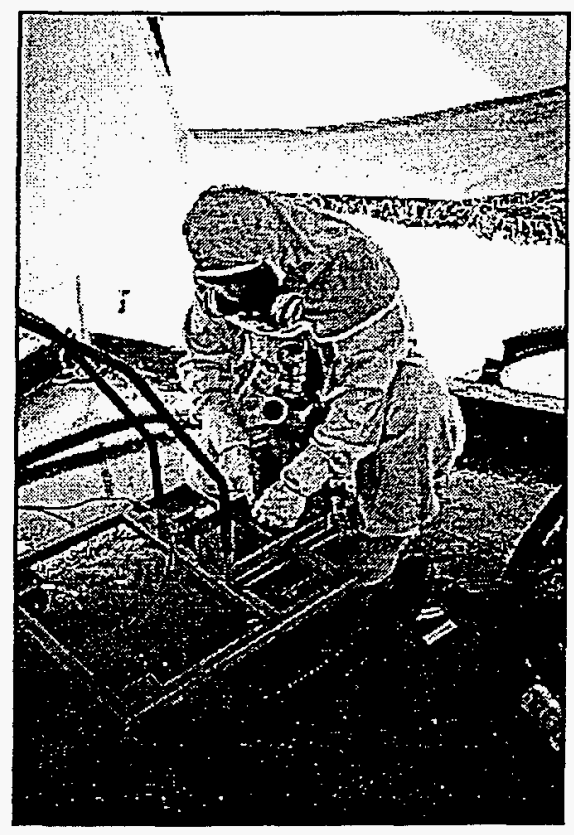

Figure 3 - Worker attaching shot head to cart.

- Communication - due to the noise generated by the technology during operation, communication can be difficult. Personnel working in the area should be familiar with and use hand signals when needed.

\section{INDUSTRIAL HYGIENE MONITORING}

During the current testing demonstration with the concrete cleaning shot blast system, sampling was conducted for dust and noise. In addition, the wet-bulb globe temperature was monitored to evaluate heat stress. Observational evaluation was conducted for ergonomics and arm-hand vibration.

Through general observational techniques the potential for ergonomic problems was evaluated during the testing demonstration. There is potential for muscle/back stress and/or injuries due to bending, twisting, and lifting associated with setup, operation, 
maintenance, and decontamination. Of particular concern is the potential for back injury due to the need to shovel the dust collected in the dust pan. This would be eliminated by the use of filters on the vacuum system.

Heat stress was monitored using a Quest QuestTemp ${ }^{\circ} 15$ Heat Stress Monitor. The wet-bulb globe temperature was used to determine the work/rest regimen in accordance with the American Conference of Governmental Industrial Hygienist (ACGIH) recommendations. The wet-bulb globe temperature was adjusted for the type of clothing, including PPE, that the worker was wearing.

In addition, the worker's blood pressure, pulse, and temperature were monitored throughout the day. No problems were encountered due to heat stress but the worker's comfort level was increased when not wearing the Anti-C PPE. While heat stress will be increased while wearing PPE, the overall heat stress response will vary from worker to worker. Each situation in which the current technology is used will need to be evaluated for the heat stress potential taking into consideration the wet-bulb globe temperature, PPE in use, physical condition of the worker, and amount of worker acclimatization.

Dust monitoring was conducted with a sampling train consisting of an SKC IOM Inhalable dust sampler coupled with a MSA Escort Elf air sampling pump. Pre-and post-sampling calibration was accomplished using a BIOS International DryCal DC1 primary calibration system. Sampling filters were desiccated pre- and post-sampling and weighed on a Denver Instrument Company A-200DS scale. Sampling was conducted in accordance with NIOSH method 0500.

Personal dust sampling was conducted on the equipment operator during blasting operations. Personal dust sampling results of $0.0 \mathrm{mg} / \mathrm{m}^{3}$ were obtained for the operator. These values do not exceed the Occupational Safety and Health Administration (OSHA) permissible exposure limit (PEL) or the ACGIH threshold limit value (TLV) of $15 \mathrm{mg} / \mathrm{m}^{3}$ and $10 \mathrm{mg} / \mathrm{m}^{3}$ respectively for total dust. There was however, a notable amount of shot left on the blasted surface. This could potentially become an airborne inhalation hazard, especially after the shot is pulverized and becomes a secondary source of dust. Due to this and the dust sampling being conducted in an outdoor environment with windy conditions, it is recommended that sampling be conducted while the shot blasting operation is being conducted in a closed environment. A complete air sampling plan for a site would need to be developed to include not only dust but other contaminants specific to the concrete decontamination project. (See Appendix B for sampling data).

Personal noise monitoring was conducted using Metrosonic db-3100 data logging noise dosimeters. Calibration was conducted pre- and post-monitoring using a Metrosonics CL304 acoustical calibrator. Monitoring was conducted on the operator for 1.2 hours (72 minutes) during operation of the centrifugal shot blast system. Monitoring during 
this time showed a noise dose of $17.36 \%$ which gives an 8-hour time-weighted average (TWA) of $77.4 \mathrm{dBA}$. If the operator continued to have the same level of noise exposure during the 8-hour shift, a projected 8-hour TWA would produce a noise dose of $116.95 \%$, or an 8-hour TWA of $91.1 \mathrm{dBA}$. Additional operator measurements for 2.9 hours (174 minutes) showed a noise dose of $47.37 \%$, which gives an 8-hour TWA of $84.6 \mathrm{dBA}$. If the operator continued to have the same level of noise exposure during the 8-hour shift, a projected 8-hour TWA would produce a noise dose of $130.63 \%$ or an 8-hour TWA of $91.9 \mathrm{dBA}$.

Monitoring was also conducted on the operator's assistant for 1.1 hours (67 minutes) during operation of the centrifugal shot blaster. Monitoring showed a noise dose of $6.30 \%$, which gives an 8 -hour TWA of $70.1 \mathrm{dBA}$. If the assistant continued to have the same level of noise exposure during the 8-hour shift a projected 8-hour TWA would produce a noise dose of $57.23 \%$ or an 8 -hour TWA of $85.97 \mathrm{dBA}$.

The OSHA allowable PEL for noise is a $100 \%$ dose or an 8 -hour TWA of $90 \mathrm{dBA}$. The above noise doses and TWA's show a potential for overexposure, depending on the amount of time spent operating the equipment. Neither the operator nor the assistant were over-exposed after 2.9 hours, 1.2 hours, or 1.1 hours of operation, but may be over-exposed after an 8-hour work shift. At these exposure levels, personnel may be required to be included in a hearing conservation program. Feasible engineering controls, administrative controls, and personal protective equipment (PPE-hearing protection devices) need to be used as appropriate. The percentage of time spent at each noise level that comprises the exposures can be seen in Appendix B.

During the 1.1 hours of operation for the assistant, the noise levels were averaged for each one-minute period of time. An overall average was calculated, yielding an average exposure level of $86.0 \mathrm{dBA}$ for an $80 \mathrm{~dB}$ cutoff level, and $83.4 \mathrm{dBA}$ for a $90 \mathrm{~dB}$ cutoff level. The average exposure level for the operator was $91.1 \mathrm{dBA}$ for an $80 \mathrm{db}$ cutoff level, and $90.6 \mathrm{dBA}$ for a $90 \mathrm{db}$ cutoff level for the 1.2 hours of operation; and $91.9 \mathrm{dBA}$ for an $80 \mathrm{~dB}$ cutoff, and $91.0 \mathrm{dBA}$ for a $90 \mathrm{~dB}$ cutoff level for the 2.9 hours of operation. OSHA requires an $80 \mathrm{db}$ cutoff for hearing conservation measurements and a $90 \mathrm{db}$ cutoff for engineering controls compliance measurements. The maximum sound level observed during the measurement period was $105.8 \mathrm{dBA}$ for the assistant and $118.8 \mathrm{dBA}$ for operator. The highest instantaneous sound pressure level was $130.0 \mathrm{~dB}$ for the assistant and $138.6 \mathrm{~dB}$ and $138.9 \mathrm{~dB}$ for the operator.

These measurements define noise as a potential exposure problem for personnel operating and assisting with the operation of the concrete cleaning centrifugal shot blaster system. It must also be noted that the equipment was being operated in an open outdoor environment at the time of the measurements. Operation in an enclosed facility would have the potential to increase the noise level due to other influences such as vibration and reverberation. Therefore it is recommended that noise monitoring be conducted while the equipment is being operated in a closed environment. 


\section{JOB SAFETY ANALYSIS Concrete Cleaning, INC. Centrifugal Shot Blaster}

\begin{tabular}{|c|c|}
\hline \multicolumn{2}{|r|}{ CORRECTIVE ACTION } \\
\hline \multicolumn{2}{|c|}{ UNLOADING EQUIPMENTISETUP } \\
\hline Pinch Points & $\begin{array}{l}\text { * Use of hand protection } \\
{ }^{*} \text { Use of proper hand tools for the job }\end{array}$ \\
\hline Slips/Trips/Falls & $\begin{array}{l}\text { * Awareness of the specific hazards } \\
\text { * Organizing of materials (housekeeping) } \\
\text { * Walking around areas that are } \\
\text { wet/slippery when possible. } \\
\text { * Walking around tripping hazards when } \\
\text { possible }\end{array}$ \\
\hline Struck by/Caught between & $\begin{array}{l}\text { * Awareness of where equipment is being } \\
\text { moved to at all times } \\
\text { * Prohibit worker from being between } \\
\text { moving and stationary objects at all times } \\
{ }^{*} \text { Keep personnel clear of moving objects } \\
\text { * Use of proper warning devices on } \\
\text { equipment }\end{array}$ \\
\hline Falling from above hazard & $\begin{array}{l}\text { * Prohibit workers from being under or } \\
\text { too close to moving objects } \\
\text { * Only use equipment appropriate for the } \\
\text { load } \\
\text { * Inspection program for equipment used } \\
\text { to move heavy objects to assure in safe } \\
\text { operating condition }\end{array}$ \\
\hline
\end{tabular}


HAZARD

Muscular/Back Injury

Electrical Hazards

\section{CORRECTIVE ACTION}

* Ergonomics training including safe lifting techniques

* Use of equipment such as forklift or crane for unloading

${ }^{*}$ Assure worker properly trained in electrical safety

* Assure all equipment properly grounded and use of ground fault circuit breakers.

\section{CHECKING BLAST AREA FOR "HOT SPOT"}

\begin{tabular}{|c|c|}
\hline Burn Hazard & $\begin{array}{l}\text { * Wear gloves appropriate for use with } \\
\text { hot surfaces } \\
\text { * Worker awareness of potential for burn }\end{array}$ \\
\hline \multicolumn{2}{|c|}{ BLASTING CONCRETE } \\
\hline Slips/Trips/Falls & $\begin{array}{l}\text { * Awareness of site specific } \\
\text { hazards/cords/tether lines/etc. } \\
\text { * Job site organization of materials } \\
\text { (housekeeping) } \\
\text { * Walk around hazards when possible }\end{array}$ \\
\hline Restricted Communication & *Hand signals as SOP's \\
\hline Noise & $\begin{array}{l}\text { *Use engineering controls } \\
\text { *Provide proper PPE devices and training } \\
\text { *Use administrative controls }\end{array}$ \\
\hline Struck by/caught between & $\begin{array}{l}\text { * Prohibit workers from being in front of } \\
\text { the operating shot blaster } \\
\text { * Prohibit workers from being between } \\
\text { running machine and stationary object }\end{array}$ \\
\hline
\end{tabular}




\begin{tabular}{|c|c|}
\hline HAZARD & CORRECTIVE ACTION \\
\hline Exposure to Contaminant and Shot & $\begin{array}{l}\text { * Unitization of proper PPE, including } \\
\text { respiratory protection } \\
\text { * Better utilization of vacuum system } \\
\text { *Use of HEPA filters with vacuum system }\end{array}$ \\
\hline Pinch Points & $\begin{array}{l}\text { * Use of hand protection } \\
\text { * Remote operations when possible }\end{array}$ \\
\hline Muscular/Back Injury & $\begin{array}{l}\text { * Limit duration of work } \\
\text { * Training on proper lifting techniques }\end{array}$ \\
\hline Spread of Contamination & * Better utilization of vacuum system \\
\hline \multicolumn{2}{|c|}{ DUMPING DUST PAN } \\
\hline Exposure to Contaminants & $\begin{array}{l}\text { * Use a vacuum system with HEPA filters } \\
\text { * Use of proper PPE, including } \\
\text { respiratory protection }\end{array}$ \\
\hline Muscular/Back Injury & $\begin{array}{l}\text { * Use mechanical means for removal of } \\
\text { dust/dust pan }\end{array}$ \\
\hline Slips/Trips/Falls & $\begin{array}{l}\text { * Awareness of the specific hazards } \\
\text { * Organizing of materials (housekeeping) } \\
\text { * Walking around areas that are wet } \\
\text { Islippery when possible } \\
\text { * Walking around tripping hazards when } \\
\text { possible }\end{array}$ \\
\hline Pinch Points & $\begin{array}{l}\text { * Hand protection } \\
\text { * Use of hand tools appropriate for the } \\
\text { job when possible }\end{array}$ \\
\hline Restricted Communication & $\begin{array}{l}\text { * Use of hand signals as SOP's } \\
\text { * Reduce power/noise while changing }\end{array}$ \\
\hline
\end{tabular}




\section{HAZARD}

CORRECTIVE ACTION

\begin{tabular}{|c|c|}
\hline \multicolumn{2}{|c|}{ GENERAL MAINTENANCE } \\
\hline Exposure to contaminant & $\begin{array}{l}\text { * Wear proper PPE and respiratory } \\
\text { protection - may need additional gloves } \\
\text { over anti-C gloves to avoid tears and rips } \\
\text { to gloves } \\
\text { * Have something to sit or kneel on so do } \\
\text { not have additional personnel exposure } \\
\text { from sitting or kneeling on contaminated } \\
\text { surface }\end{array}$ \\
\hline Accidental activation of moving parts & * Use proper lockout/tagout techniques \\
\hline Pinch Points & $\begin{array}{l}\text { * Use of hand protection } \\
\text { * Use of hand tools appropriate for the } \\
\text { job }\end{array}$ \\
\hline Slips/Trips/Falls & $\begin{array}{l}\text { * Awareness of the specific hazards } \\
\text { * Organizing of materials (housekeeping) } \\
\text { * Walking around areas that are } \\
\text { wet/slippery when possible } \\
\text { * Walking around tripping hazards when } \\
\text { possible }\end{array}$ \\
\hline $\begin{array}{l}\text { Ergonomics/Bending/Kneeling/ } \\
\text { Lifting }\end{array}$ & $\begin{array}{l}\text { * Limit duration of work } \\
\text { * Use proper lifting techniques } \\
\text { * Perform maintenance on elevated work } \\
\text { platform } \\
\text { * Ergonomics training to include proper } \\
\text { lifting techniques }\end{array}$ \\
\hline
\end{tabular}




\section{FAILURE MODES AND EFFECTS ANALYSIS CONCRETE CLEANING, INC. CENTRIFUGAL SHOT BLAST}

\begin{tabular}{|l|l|}
\hline Lose vacuum pressure & $\begin{array}{l}\text { *Potential for higher concentration of } \\
\text { contaminant to be released into } \\
\text { atmosphere } \\
\text { *Potential for greater amount of shot to } \\
\text { be left on surface }\end{array}$ \\
\hline Vacuum line is punctured/ruptured & $\begin{array}{l}\text { *Potential for higher concentration of } \\
\text { contaminant to be released into } \\
\text { atmosphere }\end{array}$ \\
\hline $\begin{array}{l}\text { Improper grounding of electrical } \\
\text { components }\end{array}$ & $\begin{array}{l}\text { *Potential electrocution hazard for } \\
\text { workers }\end{array}$ \\
\hline Lose power & $\begin{array}{l}\text { *Equipment shuts down with potential to } \\
\text { momentarily release higher concentration } \\
\text { of conteminant into atmosphere }\end{array}$ \\
\hline E-stop fails & $\begin{array}{l}{ }^{*} \text { Potential for injury as a result of } \\
\text { condition that caused the E-stop to be } \\
\text { used }\end{array}$ \\
\hline
\end{tabular}




\section{TECHNOLOGY SAFETY DATA SHEET}

\section{CONCRETE CLEANING, INC. CENTRIFUGAL SHOT BLAST}

\begin{tabular}{|l|l|}
\hline SECTION 1: TECHNOLOGY IDENTITY \\
\hline Manufacturer's Name and Address: & $\begin{array}{l}\text { Emergency Contact: } \\
\text { Mike Connacher } \\
(509) 226-0315\end{array}$ \\
\cline { 2 - 2 } $\begin{array}{l}\text { Concrete Cleaning, Inc. } \\
\text { Ot10 N. Ormond }\end{array}$ & $\begin{array}{l}\text { Information Contact: } \\
\text { Mike Connacher } \\
(509) 226-0315\end{array}$ \\
\cline { 2 - 2 } & Date Prepared: \\
\hline $\begin{array}{l}\text { Other Names: } \\
\text { Shot Blaster }\end{array}$ & Signature of Preparer: \\
\hline
\end{tabular}

\section{SECTION 2: PROCESS DESCRIPTION}

The centrifugal shot blaster is a an electronically operated shot blast machine that has been modified to remove layers of concrete to varying depths. A hardened steel shot propelled at a high rate of speed abrades the surface of the concrete. The depth of material removed is determined by the rate of speed the machine is traveling and the volume of shot being fired into the blast chamber. The steel shot is recycled and reused until it is pulverized into dust, which ends up in the waste container with the concrete being removed. Debris is continually vacuumed by a large dust collection system attached to the shot blaster. 


\section{SECTION 3: PROCESS DIAGRAM}

A process diagram is not available from the manufacturer for the Concrete Cleaning, Inc. Centrifugal Shot Blast. To better understand the process for using the shot blaster, a process diagram should be obtained from the manufacturer of the equipment before use.

\section{SECTION 4: CONTAMINANTS AND MEDIA}

The technology has the potential to cause concrete dust and associated contaminants to become airborne. Specific contaminants need to be evaluated on a site-by-site, job-by-job basis to determine the potential for exposure.

\begin{tabular}{|c|c|c|}
\hline \multicolumn{3}{|c|}{ SECTION 5: ASSOCIATED SAFETY HAZARI } \\
\hline \multicolumn{3}{|c|}{$\begin{array}{cl}\text { Probability of Occurrence of Hazard: } \\
1 & \text { Hazard may be present but not expected over background level } \\
2 & \text { Some level of hazard above background level known to be present } \\
3 & \text { High hazard potential } \\
4 & \text { Potential for imminent danger to life and health }\end{array}$} \\
\hline A. ELEC & ICAL (LOCKOUTITAGOUT) & RISK RATING: 2 \\
\hline \multicolumn{3}{|c|}{$\begin{array}{l}\text { Technology has the potential for electrical hazards. Assure proper grounding, use c } \\
\text { ground fault circuit interrupters, and stress relievers on all equipment. Compliance } \\
\text { with applicable electrical standards and codes and lockout/tagout procedures must } \\
\text { be followed to assure the safety of personnel. }\end{array}$} \\
\hline B. FIRE & BEXPLOSION & RISK RATING: 1 \\
\hline \multicolumn{3}{|c|}{$\begin{array}{l}\text { Technology does not pose this hazard in and of itself but could not be used in an } \\
\text { explosive environment due to the potential for sparking. }\end{array}$} \\
\hline \multicolumn{2}{|c|}{ C. CONFINED SPACE ENTRY } & RISK RATING: 1 \\
\hline \multicolumn{3}{|c|}{$\begin{array}{l}\text { Not part of this technology unless the specific location where shotblast is being usec } \\
\text { is a confined space. In this case, confined space procedures would need to be } \\
\text { followed. }\end{array}$} \\
\hline
\end{tabular}


SECTION 5: ASSOCIATED SAFETY HAZARDS

D. MECHANICAL HAZARDS

RISK RATING: 4

Use of large equipment and hand tools may pose the following: pinch points, struck by, caught between, and fall from above hazards.

E. PRESSURE HAZARDS RISK RATING: N/A

Not part of this technology.

F. TRIPPING AND FAL LING

RISK RATING: 3

Electrical cords present tripping hazards.

G. LADDERS AND PLATFORMS

RISK RATING: N/A

Not part of this technology.

H. MOVING VEHICLES

RISK RATING: 3

The presence of multiple pieces of mobile equipment (used to unload and load the technology) in relationship to a small area of operation may pose a significant danger. Sufficient warning devices such as horn, bells, lights and back up alarms should be utilized. Personnel should be trained to work with and around moving equipment.

1. BURIED UTILITIES, DRUMS, AND TANKS

RISK RATING: N/A

Not part of this technology.

J. PROTRUDING OBJECTS

RISK RATING: N/A

Not part of this technology.

K. GAS CYLINDERS

RISK RATING: N/A

Not part of this technology.

L. TRENCHING AND EXCAVATIONS

RISK RATING: N/A

Not part of this technology.

M. OVERHEAD LIFTS

RISK RATING: 4

Unloading and loading of technology may require overhead lifts or the use of a forklift. Proper precautions indicated.

N. OVERHEAD HAZARDS RISK RATING: 2

Would only be present if a crane were required to unload or load equipment. 


\section{SECTION 6: ASSOCIATED HEALTH HAZARDS}

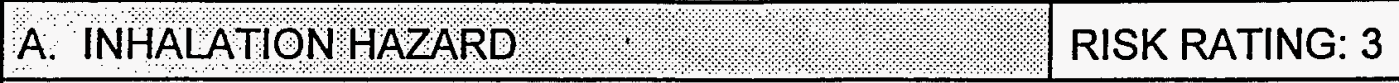

Technology produces dust from the concrete and concrete contamination. Specific hazards will be identified from the site characterization. Evaluation of total dust and/or respirable dust generated should be conducted. The shot may also present an inhalation hazard especially as it becomes pulverized.

B. SKIN ABSORPTION

RISK RATING: 2

This would be dependent on the contaminants at the site and would be identified by the site characterization.

\section{HEAT STRESS}

RISK RATING: 4

Ambient atmospheric conditions correlated with PPE levels must be considered.

D. NOISE RISK RATING: 3

The technology presents the potential for a noise hazard.

E. NON-IONIZING RADIATION

RISK RATING: N/A

Not part of this technology.

F. IONIZING RADIATION

RISK RATING: $1-4$

None associated with this technology, but the contaminated concrete may present a significant radiation exposure. This will be identified by the site characterization.

G. COLD STRESS

RISK RATING: 1

Technology does not produce a hazard, but ambient conditions need to be considered.

H. ERGONOMIC HAZARDS

RISK RATING: 3

Poses ergonomic hazards associated with lifting, bending, twisting, stooping, kneeling. These may cause injury/strain to the back, knees, hips, and/or legs.

1. OTHER

RISK RATING: N/A

None noted. 


\section{SECTION 7: PHASE ANALYSIS}

\section{A. CONSTRUCTIONISTART UP}

The set-up/start-up phase presents several hazards including pinch points, slips/trips/falls, struck by/caught between, falling from above, muscular/back injury, and electrical.

\section{B. OPERATION}

The operational phase presents several hazards including exposure to contaminant (airborne and from the surface), muscular/back injury, mechanical hazards, electrical hazards, and exposure to noise.

\section{MAINTENANCE}

The maintenance phase presents several hazards including pinch points, slips/trips/falls, struck by/caught between, muscular/back injury, electrical, exposure to contaminants (airborne and from the surface), and accidental activation of moving parts.

\section{DECOMMISSIONING}

The decommissioning phase presents several hazards including exposure to the contaminant, pinch points, slips/trips/falls, and muscular/back injury.

\section{SECTION 8: HEALTH AND SAFETY PLAN REQUIRED ELEMENTS}

A. AIR MONITORING

When concrete is blasted, total and respirable dust need to be monitored. Monitoring also needs to be done for specific concrete contaminants and may need to be conducted for specific constituents of the concrete such as silica. In addition, noise monitoring is essential.

\section{B. WORKER TRAINING}

Training that would apply in this case may include but not be limited to: HAZWOPER (Hazardous Waste Operations and Emergency Response), HAZCOM (Hazard Communication), Respiratory Protection, Hearing Conservation, Ergonomics (proper lifting, bending, stooping, kneeling), specific training for equipment operation, CPR/First Aid/Emergency Response/Bloodborne Pathogens, Electrical Safety, Lockout/Tagout, Radiation Safety, Hand Signal Communication, Construction Safety (OSHA 500) and or General Industry Safety (OSHA 501) 


\section{SECTION 8: HEALTH AND SAFETY PLAN REQUIRED ELEMENTS}

C. EMERGENCY RESPONSE

Emergency response planning for a site needs to assure adequate coverage for hazards described in the TSDS. Having as many workers as possible trained in CPR and first aid is recommended.

D. MEDICAL SURVEIL LANCE

Evaluation of personnel's general health with emphasis on the cardiovascular and respiratory system, back, and peripheral nervous system. Annual audiograms.

E. INFORMATIONAL PROGRAM

Workers must be trained in specific operation of equipment before use.

SECTION 9: COMMENTS AND SPECIAL CONSIDERATIONS

Due to the noise produced, communication may become difficult. Personnel working in the area should be familiar with and use hand signals as necessary.

Only personnel who have been adequately trained in the operation of this technology should be permitted to operate and/or work with the equipment. 


\section{HUMAN FACTORS INTERFACE}

The technologies being tested for concrete decontamination and decommissioning are targeted for alpha contaminated concrete. Therefore, the equipment operator and assistant were dressed out in Anti-C (alpha radiation) PPE which included cloth suit, hood, inner and outer boots, inner and outer gloves, and full face air-purifying respirator. Due to the full face respirator, the operators had some visibility problems while operating the equipment. There was also a decrease in dexterity due to the gloves which caused some problems during maintenance activities because of a loss of tactile sensation. In addition, the need to perform work in the Anti-C PPE caused some increase in heat stress for the operator and assistant.

If the concrete being decontaminated had contamination other than or in addition to alpha radiation, additional levels of protection, such as Level A or Level B PPE, may be required for the operator. These may create additional human interface problems such as a greater decrease in visibility and manual dexterity, an increase in heat stress, and an overall increase in physical stress. It is recommended that additional safety and health evaluations be conducted utilizing these higher levels of protection.

The main ergonomic concern was shoveling the dust collected in the dust pan. This greatly increased the potential for exposure to the dust and associated contaminants and presented an extreme potential for back injury from shoveling.

\section{EMERGENCY RESPONSEIPREPAREDNESS}

The use of the Concrete Cleaning shot blast technology would not be applicable to emergency response.

Emergency response/preparedness must be part of every hazardous waste site safety and health plan. In addition to credible site emergencies, site personnel must plan for credible emergencies in connection with the centrifugal shot blaster.

All precautions used when responding to an emergency situation at the site will apply. Before entering an area where the centrifugal shot blaster is being used, the equipment needs to be completely shut down (de-energized).

This technology does not appear to present any conditions that would lead to out of the ordinary emergencies. 


\section{SECTION 4 \\ TECHNOLOGY APPLICABILITY}

On observation the technology did not deposit much visible dust into the atmosphere and air monitoring did not show a significant dust level but this was difficult to assess due to the windy outdoor testing environment. There was a large amount of shot left on the surface during blasting operation. The system needs to be evaluated to determine if an increase in vacuum air flow would help with this problem.

The centrifugal shot blast will need to be torn down to be decontaminated. This will not necessarily guarantee that decontamination for alpha will be complete and it will be difficult to survey for alpha contamination due to all of the small hard to reach (with a probe) spaces inherent in the equipment. There is also concern for the amount of contamination that may have been spread to the internal parts of the equipment when shot that has been on the surface is deposited back into the shot blaster for use.

\section{SECTION 5 REGULATORYIPOLICY ISSUES}

The site safety and health personnel where the concrete cleaning centrifugal shot blast technology is being used need to be concerned with safety and health regulations applicable to the issues discussed above. Regulations that apply may be divided into four categories. Core requirements are those regulations that would apply to any hazardous waste work site, regardless of the type of job. Technology specific requirements are those regulations that apply due to the specific technology being used. Special requirements are standards and policies that are specific to the technology itself but are not required by reference in a regulation. Best management practices are not required but are recommended by organizations such as the American National Standards Institute (ANSI), the National Institute of Occupational Health and Safety (NIOSH), Department of Energy (DOE), National Fire Protection Association (NFPA), etc. These regulations/standards may include but not be limited to the following:

\section{Core requirements:}

- OSHA 29 CFR 1926.25 Housekeeping

- OSHA 29 CFR 1910.141 Sanitation (1910.141(a)(3) covers housekeeping)

- OSHA 29 CFR 1926.53 lonizing Radiation 
- OSHA 29 CFR 1910.96 lonizing Radiation

- OSHA 29 CFR 1926 Subpart Z Toxic and Hazardous Substances

- OSHA 29 CFR 1910 Subpart Z Toxic and Hazardous Substances

- OSHA 29 CFR 1926.59 Hazard Communication

- OSHA 29 CFR 1910.1200 Hazard Communication

- OSHA 29 CFR 1926.64 Process Safety Management of Highly Hazardous Chemicals

- OSHA 29 CFR 1910.119 Process Safety Management of Highly Hazardous Chemicals

- OSHA 29 CFR 1926.65 Hazardous Waste Operations and Emergency Response

- OSHA 29 CFR 1910.120 Hazardous Waste Operations and Emergency Response

- Occupational Safety and Health Act 1970(5)(a)(1) General Duty Clause

Technology specific requirements:

- OSHA 29 CFR 1926 Subpart K Electrical

- OSHA 29 CFR 1910 Subpart S Electrical

- OSHA 29 CFR 1910 Subpart O Machinery and Machine Guarding

- OSHA 29 CFR 1910.147 The Control of Hazardous Energy (LockoutTagout)

- OSHA 29 CFR 1926.52 Occupational Noise Exposure

- OSHA 29 CFR 1910.95 Occupational Noise Exposure

- OSHA 29 CFR 1926.103 Respiratory Protection

- OSHA 29 CFR 1910.134 Respiratory Protection

- OSHA 29 CFR 1926.102 Eye and Face Protection

- OSHA 29 CFR 1910.133 Eye and Face Protection 
- OSHA 29 CFR 1926.28 Personal Protective Equipment

OSHA 29 CFR 1910.132 General Requirements (Personal Protective Equipment)

- OSHA 29 CFR 1926.23 First Aid and Medical Attention

$-\quad$ OSHA 29 CFR 1910.151 Medical Services and First Aid

- ACGIH Threshold Limit Values for Chemical Substances and Physical Agents and Biological Exposure Indices

In addition to the above regulations and policies, it is imperative that all workers have appropriate and adequate training for the task and associated safety and health conditions. Training that would be required may be divided into four categories. Core training is that which is required for anyone entering a hazardous waste site to perform work, regardless of the type of job. Technology specific training is that training that is specific to the technology and required by safety and health standards. Special training is that which is specific to the technology to assure the worker is adequately trained for the task but is not necessarily required by safety and health standards. Best management practices are trainings that while not mandated by health and safety standards, provide information and knowledge to the worker that will allow the worker to perform his/her job safely. Training to be applied for the centrifugal shotblast technology may include but not be limited to:

\section{Core training requirements:}

- HAZWOPER (Hazardous Waste Operations and Emergency Response)

$+\quad$ HAZCOM (Hazard Communication)

- Radiation Safety (Radiation Worker Training) for radiation sites

\section{Technology Specific Training:}

- Respiratory Protection

- Hearing Conservation

- Personal Protective Equipment

- Electrical Safety 
- Lockout/Tagout

\section{Special training:}

- Job specific training for equipment operation

\section{Best Management Practice training:}

- Ergonomics (proper lifting, bending, stooping, kneeling, safe shoveling techniques)

- Heat stress (learning to recognize signs and symptoms)

- CPR/First Aid/Emergency Response/Blood-borne Pathogens

- Hand Signal Communication

- Construction Safety (OSHA 500) and or General Industry Safety (OSHA 501)

\section{SECTION 6 OPERATIONAL CONSIDERATIONS \& RECOMMENDATIONS}

Recommendations made here for improved worker safety and health take into consideration the operation of the centrifugal shot blast without a HEPA vacuum system. Specific recommendations include:

- It needs to be assured that workers are aware of the tripping hazards associated with hoses and cords that are necessary to operate the equipment. Keeping these as orderly as possible in compliance with good housekeeping regulations will help avoid injury due to tripping. In addition, the operators had to find somewhere to place tools that were being used during operations. A specific place for tools located on the operating station would improve housekeeping in this area.

- Operators and assistants need to have training in ergonomics to assure proper techniques in lifting, bending, stooping, twisting, etc. during equipment operation and shoveling activities. It should be required that the system only be operated with a HEPA filter vacuum system.

- The equipment did not require the operator to have control of the centrifugal shot blast at all times in order to keep it running. The operator was able to leave the equipment and walk in front of or behind it. This could lead to a struck by, 
contacted by, or caught between accident. Standard Operating Procedures (SOP's) need to be developed that require the operator to stay with the equipment at all times during operation. In addition, the operator was not able to see over the equipment and had to look around it while operating to see what was in front of him. This could cause the assistant to be struck by, contacted by, or caught between the equipment and a wall surface. Mounting a camera on the front of the equipment with a viewing screen at the operators location or designing the equipment for remote operation would alleviate this problem.

- There is an E-stop located on the centrifugal shot blast but because the operator had to stand to the left of the equipment (to see in front of it) during operation, he was not within arm's length of the E-stop. This presents an increase in the potential to cause harm by whatever conditions cause the E-stop to be needed. The E-stop needs to be located within easy access of the operator at all times.

- The use of the dust pan made it necessary for the workers to shovel the accumulated dust to empty the pan. This has the potential to cause ergonomic problems such as back stress/injury and greatly increases the potential for exposure to the contaminant. The shot blaster should be used with a HEPA filter vacuum system.

- During blasting operations, there was a significant amount of shot left on the surface. This was collected using a large magnet and placed back into the blaster for reuse. Shot that is not left on the surface is recycled back into the equipment for reuse. Both of these practices have the potential to spread contamination to the internal parts of the equipment. The vacuum system needs to be evaluated to determine if an increase in air flow will help this problem.

The shot left on the surface makes it very slippery. Further, it can create a secondary waste problem, because when it gets wet it rusts. A design change to the vacuum system will also help with these problems.

- Prior to operation the operator has to check the blast area for a "hot spot." This has the potential to literally be hot and cause a burn. The operator must be aware of this and use the appropriate gloves while checking for a "hot spot."

- There is potential for overexposure to noise during operation of the technology. Since testing was done in an outdoor environment, it is plausible that the noise levels would increase in an enclosed environment. The equipment needs to be evaluated for possible engineering controls to help decrease the noise exposure to the operator. If engineering controls are not possible, administrative controls, and/or adequate hearing protection must be incorporated during operation.

Due to the windy outdoor environment in which the testing demonstration was conducted and therefore, the dust and noise monitoring was conducted, it is 
recommended that further testing for dust exposure and noise exposure be conducted while the technology is used in an enclosed environment similar to environments in which it would be used at a hazardous waste clean-up site. This would also allow for a more thorough evaluation of the heat stress to be encountered while wearing the appropriate PPE.

It is also recommended that the operation and maintenance activities be evaluated while the operator is wearing Level A and Level B PPE since these levels may be needed in environments where the concrete contamination is mixed in nature or other than radiation.

The safety and health issues discussed throughout this report could be reduced and in some cases eliminated if this type of scabbling technology could operate remotely. 


\section{APPENDIX A REFERENCES}

Occupational Safety and Health Standards for General Industry, 29 CFR Part 1910, Occupational Safety and Health Administration United States Department of Labor, 1995

Occupational Safety and Health Standards for the Construction Industry, 29 CFR Part 1926, Occupational Safety and Health Administration United States Department of Labor, 1995

Threshold Limit Values(TLV's) for Chemical Substances and Physical Agents and Biological Exposure Indices (BEl's), American Conference of Governmental Industrial Hygienists, 1995-1996

ANSI 1986, Guide for the measurement and evaluation of human exposure to vibration transmitted to the hand, New York, NY: American National Standards Institute, ANSI S3.34 


\section{APPENDIX B IH SAMPLING DATA}

\begin{tabular}{|c|c|c|c|}
\hline \multicolumn{4}{|c|}{$\begin{array}{l}\text { Concrete Cleaning, Inc. Centrifugal Shot Blast } \\
\text { Total Dust Sampling }\end{array}$} \\
\hline Date & Sample Nunber & Anatitse & Results \\
\hline $5 / 29 / 96$ & 052996-FIU-022 & Blank & $0.0000 \mathrm{mg} / \mathrm{m}^{3}$ \\
\hline $5 / 29 / 96$ & 052996-FIU-023 & Total dust & $0.0000 \mathrm{mg} / \mathrm{m}^{3}$ \\
\hline
\end{tabular}

* The OSHA PEL for total dust is $15 \mathrm{mg} / \mathrm{m}^{3}$ and the ACGIH TLV is $10 \mathrm{mg} / \mathrm{m} 3$. Current sampling was conducted for total dust. The need to sample for respirable dust and silica has to be considered during concrete decontamination and decommissioning activities. 


\section{NOISE SAMPLING}

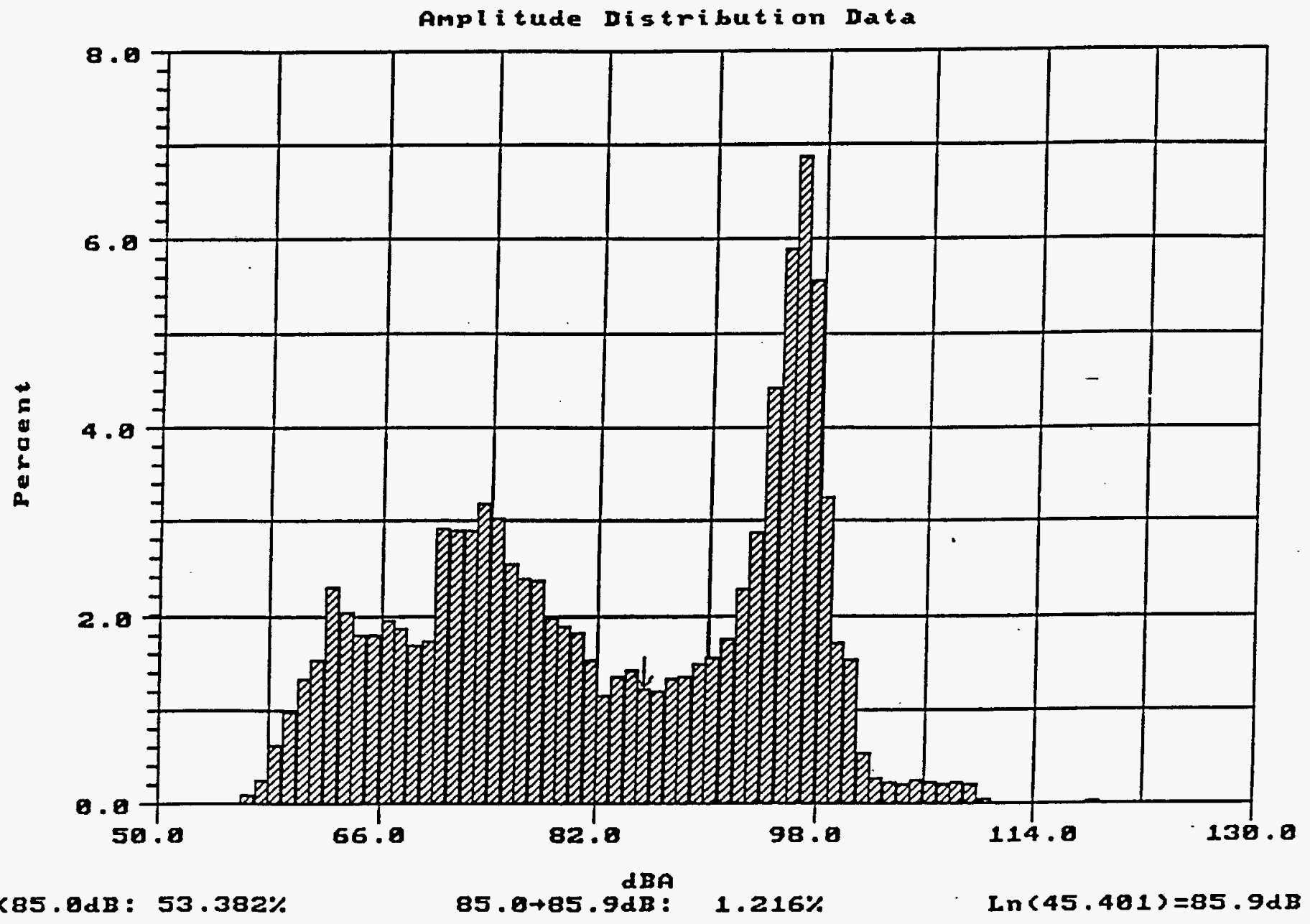

The percentage of time spent at each decibel level can be obtained from the graph. As shown, $53.382 \%$ of the time the noise exposure was less than $85 \mathrm{dBA}$ which means that the majority of the time or $46.618 \%$ of the time the noise exposure was at sound levels above $85 \mathrm{dBA}$. OSHA requires that a hearing conservation program be initiated if the 8-hour TWA is $85 \mathrm{dBA}$. 


\section{NOISE SAMPLING}

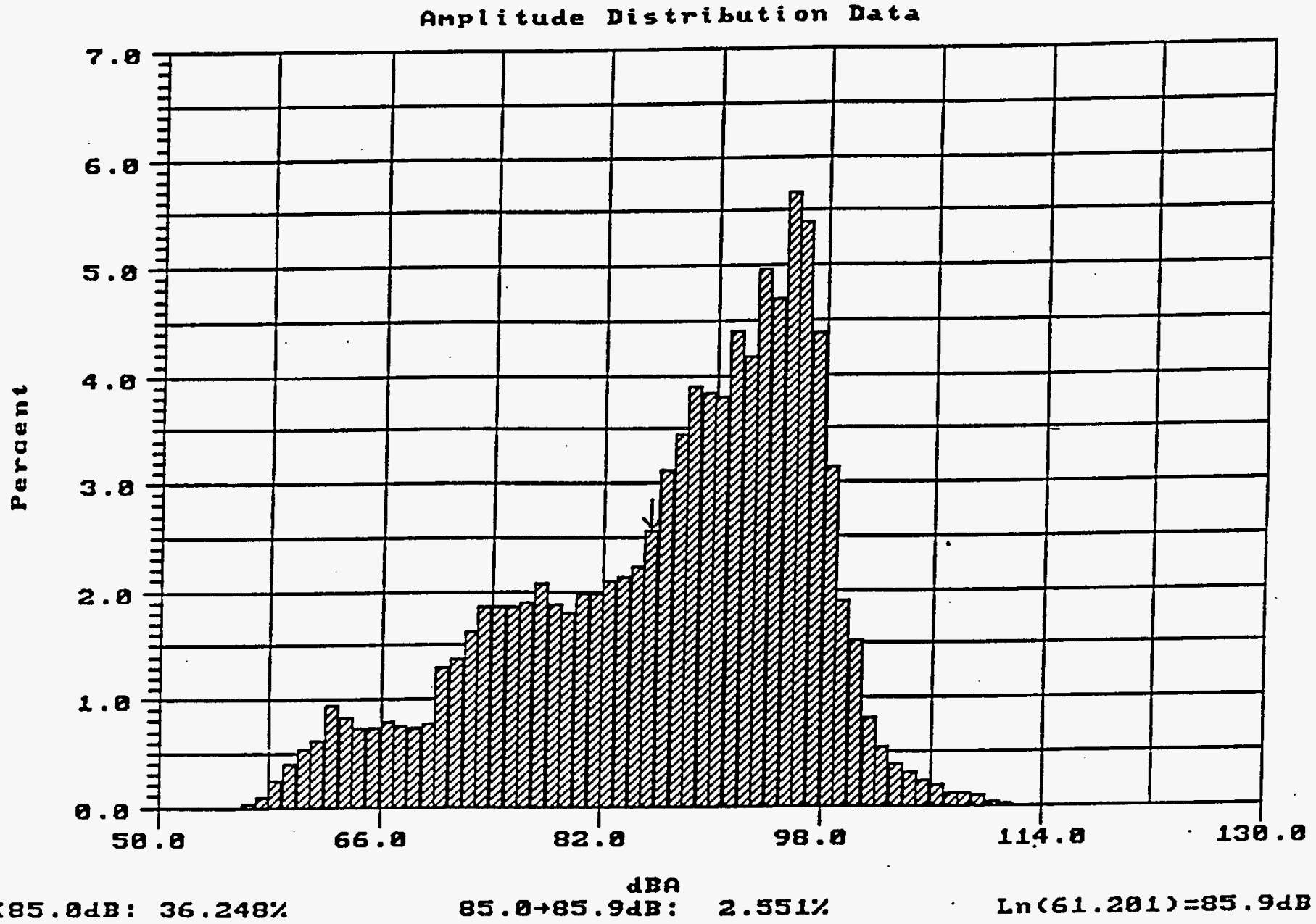

The percentage of time spent at each decibel level can be obtained from the graph. As shown, $36.248 \%$ of the time the noise exposure was less than $85 \mathrm{dBA}$ which means that the majority of the time or $63.752 \%$ of the time the noise exposure was at sound levels above $85 \mathrm{dBA}$. OSHA requires that a hearing conservation program be initiated if the 8-hour TWA is $85 \mathrm{dBA}$. 


\section{NOISE SAMPLING}

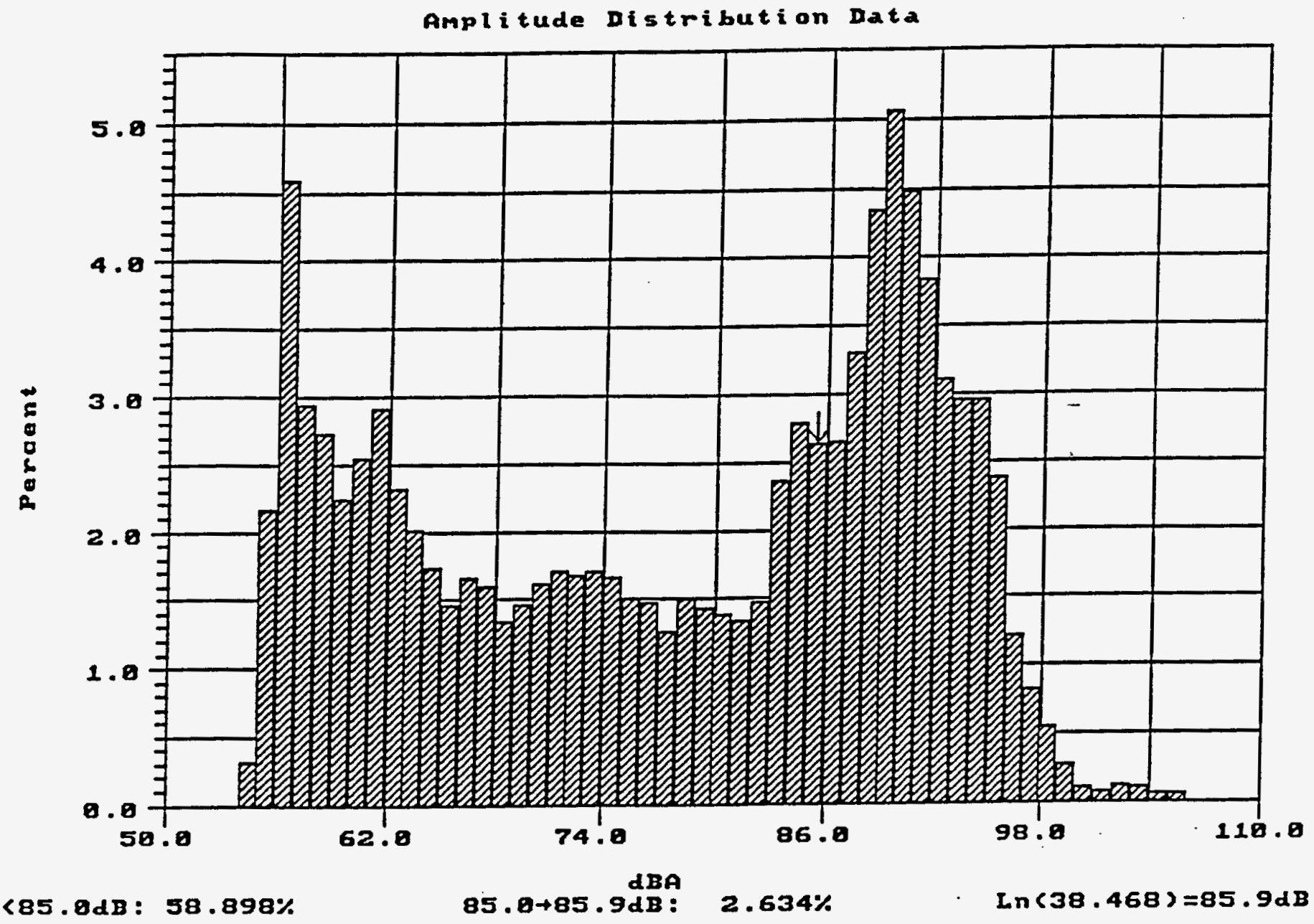

The percentage of time spent at each decibel level can be obtained from the graph. As shown, $58.898 \%$ of the time the noise exposure was less than $85 \mathrm{dBA}$ which means that the majority of the time or $41.102 \%$ of the time the noise exposure was at sound levels above $85 \mathrm{dBA}$. OSHA requires that a hearing conservation program be initiated if the 8-hour TWA is $85 \mathrm{dBA}$. 
Report Number (14) DOE/mC/32260--5834

دubl. Date (11)

(18) $\frac{19970731}{\Delta 0 \varepsilon / \varepsilon m ; \Delta O \varepsilon / F \varepsilon, X F}$

Sponsor Code (18)

JC Category (19) UC-2000; uC-101, DOE/ER 